\title{
Evaluation of the psychophysiological functions in humans exposed to trichloroethylene
}

\author{
M. SALVINI, S. BINASCHI, and M. RIVA ${ }^{1}$ \\ Institute of Preventive Medicine for Workers and Applied Psychology, University of Pavia, Italy
}

\begin{abstract}
Salvini, M., Binaschi, S., and Riva, M. (1971). Brit. J. industr. Med., 28, 293-295. Evaluation of the psychophysiological functions in humans exposed to trichloroethylene. To provide data on the psychophysiological efficiency of human beings exposed to solvent vapour currently used in the industry the effects of trichloroethylene (TCE) were evaluated by exposing six male university students to an average vapour concentration of 110 p.p.m. for two 4-hour exposures, separated by a $1 \frac{1}{2}$-hour interval. Each subject was examined on two different days, on one day undertaking a set of tests in an atmosphere contaminated with TCE vapours and on another day in a 'control' atmosphere which did not contain TCE.

On each of the two days two sets of test were performed at 8.30 a.m. and at 6 p.m. The following tests were performed: perception test with tachistoscopic presentation, Wechsler Memory Scale, complex reaction time test, and manual dexterity test. A crossed scheme analysis was used. In all the tests performed a statistically very significant decrease in performance ability was seen; the greatest decrease occurred during the more complex tests. The suggested TLV for TCE (100 p.p.m.) appears to be very close to the average concentration capable of interfering with psychophysiological efficiency, even in the absence of other undesirable subjective and objective manifestations.
\end{abstract}

Experiments performed on experimental animals to ascertain the effects of trichloroethylene (TCE) vapour have shown that this substance interfered with their psychophysiological efficiency (Grandjean and Bättig, 1964).

Recentliy, experiments have been conducted to find whether the same phenomenon occurs in humans. In one experiment, a human subject was exposed to four concentrations of TCE for 2 hours 45 minutes. The results indicated that at the TLV of TCE (100 p.p.m., as recommended by the American Conference of Governmental Industrial Hygienists, 1967), no significant effects occurred in human

${ }^{1}$ Research Laboratory Star Food Co. Ltd., Milan.

Address requests for reprints to: Istituto di Medicina Preventiva dei Lavoratori, 24, via Boezio - 27100 Pavia (Italy). psychomotive efficiency (Stopps and McLaughlin, 1967). This conclusion may be questioned on two grounds: firstly, all of Stopps's experiments were performed for a limited period, not comparable to the 8-hour working day; secondly, the results are of somewhat limited value because only one human being was exposed.

Therefore, to provide more realistic and reliable information on the psychophysiological efficiency of human beings exposed to solvent vapours currently used in industry, a research programme was initiated to evaluate the effects on six persons exposed to TCE at an atmospheric concentration of 110 p.p.m. for 8 working hours.

\section{Methods}

The effects of TCE were evaluated by exposing six male 
university students, between 20 and 22 years of age, to an average vapour concentration of 110 p.p.m.and fluctuations between 90 p.p.m. and 130 p.p.m. TCE was periodically atomized into the test room to maintain the desired concentration. The air was analysed at regular intervals by gas-chromatography. The temperature, humidity, and ventilation rates were kept constant (dry bulb temperature $20^{\circ} \mathrm{C}$; relative humidity $45 \%$ ).

Details of the experimental method are similar to those given in the companion paper (Salvini, Binaschi, and Riva, 1971).

During each exposure the following tests were applied (for details, see the companion paper):

1. Perception test with tachistoscopic presentation (exposure time $1 / 20 \mathrm{sec}$ ) - to evaluate the extension of the perceptive field, the span of perception, and the organizing capacity of stimuli in space;

2. Wechsler Memory Scale - to evaluate immediate memory and the perceptive field extension;

3. Complex reaction time - to evaluate the time lapse between different visual stimuli and the correct psychomotive response and the regularity between stimuli and response intervals.

Manual dexterity tests involving the right, left, and both hands simultaneously were also conducted.

\section{Results}

From an objective clinical standpoint, no disturbances in motor functions, co-ordination, equilibrium or behaviour patterns were observed after two 4-hour exposures to TCE. A slight sense of dizziness coincided with the maximum fluctuations in TCE concentrations. During these periods some transient eye irritation was observed. All the test subjects complained about the odour of TCE.

In all the tests performed there was a statistically significant decrease in performance ability; the greatest decrease occurred during the more complex experiments (Tables 1 to 5).

TABLE 1

Perceptive Test - Analysis of Variance

\begin{tabular}{l|rccc}
\hline & $S S Q$ & $D . F$. & $S^{2}$ & $F$ \\
\hline Trichloroethylene (TCE) & $28 \cdot 12$ & 1 & $28 \cdot 12$ & $27 \cdot 84^{3}$ \\
Mental fatigue (MF) & $2 \cdot 34$ & 1 & $2 \cdot 34$ & $2 \cdot 32$ \\
TCE × MF & $15 \cdot 81$ & 1 & $15 \cdot 81$ & $15 \cdot 65^{2}$ \\
Learning (L) & $35 \cdot 02$ & 1 & $35 \cdot 02$ & $34 \cdot 67^{3}$ \\
L $\times$ MF & $15 \cdot 75$ & 1 & $15 \cdot 75$ & $15 \cdot 59^{2}$ \\
Subjects (S) & $38 \cdot 60$ & 5 & $7 \cdot 72$ & $7 \cdot 64^{1}$ \\
S $\times$ MF & $15 \cdot 10$ & 5 & 3.02 & 2.99 \\
Error & $8 \cdot 11$ & 8 & 1.01 & \\
& & & & \\
\hline
\end{tabular}

${ }^{1} \mathrm{P}<0.05 \quad{ }^{2} \mathrm{P}<0.01 \quad{ }^{3} \mathrm{P}<0.001$

SSQ $=$ sum of square about the mean

D.F. = degrees of freedom

$\mathbf{S}^{2}=$ estimate of variance

$\mathbf{F}=$ Snedecor's variance ratio
TABLE 2

Immediate Memory Test - Analysis of Variance

\begin{tabular}{|c|c|c|c|c|}
\hline & $S S Q$ & D.F. & $S^{2}$ & $F$ \\
\hline $\begin{array}{l}\text { Trichloroethylene (TCE) } \\
\text { Mental fatigue (MF) } \\
\text { TCE } \times \text { MF } \\
\text { Learning (L) } \\
L \times \text { MF } \\
\text { Subjects (S) } \\
\text { S } \times \text { FM } \\
\text { Error }\end{array}$ & $\begin{array}{r}462 \cdot 68 \\
85 \cdot 58 \\
216 \cdot 74 \\
293 \cdot 88 \\
160 \cdot 53 \\
347 \cdot 75 \\
116 \\
135 \cdot 01\end{array}$ & $\begin{array}{l}1 \\
1 \\
1 \\
1 \\
1 \\
5 \\
5 \\
8\end{array}$ & $\begin{array}{r}462 \cdot 68 \\
85 \cdot 58 \\
216 \cdot 74 \\
293 \cdot 88 \\
160 \cdot 53 \\
69 \cdot 55 \\
23 \cdot 20 \\
16 \cdot 88\end{array}$ & $\begin{array}{c}27 \cdot 41^{3} \\
5 \cdot 51^{2} \\
12 \cdot 84^{2} \\
17 \cdot 41^{2} \\
9 \cdot 51^{1} \\
4 \cdot 12 \\
1 \cdot 37\end{array}$ \\
\hline
\end{tabular}

${ }^{1} \mathrm{P}<0.05 \quad{ }^{{ }^{2}} \mathrm{P}<0.01 \quad{ }^{3} \mathrm{P}<0.001$

TABLE 3

Complex Reaction Times (SPeEd of Responses) ANALYSIS OF VARIANCE

\begin{tabular}{|c|c|c|c|c|}
\hline & $S S Q$ & D.F. & $S^{2}$ & $F$ \\
\hline $\begin{array}{l}\text { Trichloroethylene (TCE) } \\
\text { Mental fatigue (MF) } \\
\text { TCE } \times \text { MF } \\
\text { Learning (L) } \\
\text { L } \times \text { MF } \\
\text { Subjects (S) } \\
\text { S } \times \text { MF } \\
\text { Error }\end{array}$ & $\begin{array}{r}119 \cdot 72 \\
77 \cdot 04 \\
127 \cdot 37 \\
87 \cdot 71 \\
46 \cdot 44 \\
162 \cdot 80 \\
105 \\
36 \cdot 68\end{array}$ & $\begin{array}{l}1 \\
1 \\
1 \\
1 \\
1 \\
5 \\
5 \\
8\end{array}$ & $\begin{array}{r}119 \cdot 72 \\
77 \cdot 04 \\
127 \cdot 37 \\
87 \cdot 71 \\
46 \cdot 44 \\
32 \cdot 45 \\
21 \\
4 \cdot 58\end{array}$ & $\begin{array}{c}26 \cdot 14^{3} \\
16 \cdot 82^{2} \\
27 \cdot 81^{3} \\
19 \cdot 15^{2} \\
10 \cdot 14^{1} \\
7 \cdot 11^{1} \\
4 \cdot 59\end{array}$ \\
\hline
\end{tabular}

${ }^{1} \mathrm{P}<0.05 \quad{ }^{2} \mathrm{P}<0.01 \quad{ }^{3} \mathrm{P}<0.001$

TABLE 4

COMPLEX ReAction Times (Regularity OF RESPONSES) - ANALYSIS OF VARIANCE

\begin{tabular}{|c|c|c|c|c|}
\hline & $S S Q$ & D.F. & $S^{2}$ & $F$ \\
\hline $\begin{array}{l}\text { Trichloroethylene (TCE) } \\
\text { Mental fatigue (MF) } \\
\text { TCE } \times \text { MF } \\
\text { Learning (L) } \\
\mathbf{L} \times \mathbf{M F} \\
\text { Subject (S) } \\
\mathbf{S} \times \mathbf{M F} \\
\text { Error }\end{array}$ & $\begin{array}{r}132 \cdot 54 \\
19 \cdot 65 \\
22 \cdot 86 \\
18 \cdot 48 \\
8 \cdot 76 \\
108 \cdot 95 \\
101 \cdot 45 \\
85 \cdot 41\end{array}$ & $\begin{array}{l}1 \\
1 \\
1 \\
1 \\
1 \\
5 \\
5 \\
8\end{array}$ & $\begin{array}{r}132 \cdot 54 \\
19 \cdot 65 \\
22 \cdot 86 \\
18 \cdot 48 \\
8 \cdot 76 \\
21 \cdot 79 \\
20 \cdot 29 \\
10 \cdot 68\end{array}$ & $\begin{array}{c}12 \cdot 41^{2} \\
1 \cdot 84 \\
2 \cdot 04 \\
1 \cdot 73 \\
0 \cdot 82 \\
2 \cdot 04 \\
1 \cdot 90\end{array}$ \\
\hline
\end{tabular}

${ }^{2} \mathrm{P}<0.01$

\section{Discussion}

Our results indicate that the suggested TLV for trichloroethylene (100 p.p.m.) appears to be very close to the average concentration capable of causing significant decrements in the functions essential to the safety of workers performing industrial operations. 
TABLE 5

Manual Ability and DeXterity - ANAlysis of VARIANCE

\begin{tabular}{|c|c|c|c|c|c|}
\hline & & $S S Q$ & D.F. & $S^{2}$ & $F$ \\
\hline (a) & $\begin{array}{l}\text { Right hand } \\
\text { Trichloroethylene } \\
\text { Learning } \\
\text { Subjects } \\
\text { Error }\end{array}$ & $\begin{array}{r}480 \cdot 11 \\
173 \cdot 61 \\
295 \cdot 95 \\
75 \cdot 42\end{array}$ & $\begin{array}{l}1 \\
1 \\
5 \\
4\end{array}$ & $\begin{array}{r}480 \cdot 11 \\
173 \cdot 61 \\
59 \cdot 19 \\
18 \cdot 85\end{array}$ & $\begin{array}{c}25 \cdot 47^{2} \\
9 \cdot 21^{1} \\
3 \cdot 14\end{array}$ \\
\hline (b) & $\begin{array}{l}\text { Left hand } \\
\text { Trichloroethylene } \\
\text { Learning } \\
\text { Subjects } \\
\text { Error }\end{array}$ & $\begin{array}{r}83 \cdot 39 \\
37 \cdot 79 \\
401 \cdot 85 \\
14 \cdot 51\end{array}$ & $\begin{array}{l}1 \\
1 \\
5 \\
4\end{array}$ & $\begin{array}{r}83 \cdot 39 \\
37 \cdot 79 \\
80 \cdot 37 \\
3 \cdot 63\end{array}$ & $\begin{array}{l}23 \cdot 80^{1} \\
10 \cdot 41^{1} \\
22 \cdot 14^{2}\end{array}$ \\
\hline (c) & $\begin{array}{l}\text { Right and left hands } \\
\text { Trichloroethylene } \\
\text { Learning } \\
\text { Subjects } \\
\text { Error }\end{array}$ & $\begin{array}{r}71 \cdot 88 \\
68 \cdot 88 \\
308 \cdot 65 \\
10 \cdot 51\end{array}$ & $\begin{array}{l}1 \\
1 \\
5 \\
4\end{array}$ & $\begin{array}{r}71 \cdot 88 \\
68 \cdot 88 \\
61 \cdot 73 \\
2 \cdot 63\end{array}$ & $\begin{array}{l}27 \cdot 33^{2} \\
26 \cdot 19^{2} \\
23 \cdot 47^{2}\end{array}$ \\
\hline
\end{tabular}

${ }^{1} \mathrm{P}<0.05 \quad{ }^{2} \mathrm{P}<0.01$

At first it was thought that these experiments could not be regarded as representative because of the complaints and reactions of the students about the odour of TCE. These reactions were considered psychological in nature because the students were never before exposed and therefore not accustomed to the odour of TCE. Neverthless, it was not known if and to what degree this factor affected the test results. For this reason, the experiment was repeated using as the subjects six workmen who regularly work with TCE and other solvents. The results of the experiments with workers confirmed the conclusions already drawn from the results with students and summarized in Tables 1 to 5.

\section{Conclusion}

Two 4-hour exposures, separated by a $1 \frac{1}{2}$-hour interval, to trichloroethylene at an average concentration of 110 p.p.m., with fluctuations ranging from 90 p.p.m. to 130 p.p.m., caused a statistically significant reduction in efficiency of both students and workers in performing various psychophysiological tests. The reduction in efficiency is particularly significant in those tests involving perceptive discrimination.

Therefore, it is possible that a TLV of 100 p.p.m. for trichloroethylene may result in interference with the psychophysiological efficiency of a man with executive or technical responsibilities even in the absence of other undesirable subjective and objective manifestations.

\section{References}

Grandjean, E., and Bättig, K. (1964). Le spectre des effets du trichloréthylène sur le comportement du rat. Arch. int. Pharmacodyn., 147, pp. 333-350.

Horváth, M., Frantík, E., and Michalová, C. (1964). The research of higher nervous functions in occupational health. Proc. XIV int. Congr. occup. Hlth Madrid, 1963, vol. II, pp. 93-105. Excerpta med. Int. Congr. Ser. No. 62.

Lyublina, E. I. (1961). Some methods used in establishing the maximum allowable concentrations. Pure appl. Chem., 3, 109-113.

Salvini, M., Binaschi, S., and Riva, M. (1971). Evaluation of the psychophysiological functions in humans exposed to the threshold limit value of 1,1,1-trichloroethane. Brit. J. industr. Med., 28, 286-292.

Stopps, G. J., and McLaughlin, M. (1967). Psychophysiological testing of human subjects exposed to solvent vapors. Amer. industr. Hyg. Ass. J., 28, 43-50.

Received for publication March 21, 1970. 